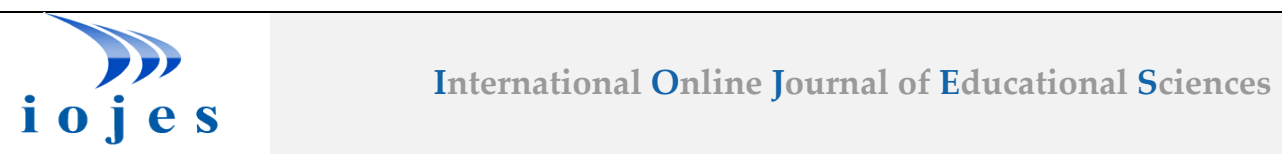

\title{
Opinions of Teachers on the Implementation of the Orff-Schulwerk Approach in Online Lessons
}

\author{
Research Article \\ Gulsah SEVER ${ }^{1}$ \\ ${ }^{1}$ Gazi University, Faculty of Education, Department of Music Education, Ankara, Turkey, ORCID: 0000-0003-0559-6993
}

To cite this article: Sever, G. (2021). Opinions of teachers on the implementation of the orff-schulwerk approach in online lessons, International Online Journal of Educational Sciences, 13(4), 949-964.

\begin{tabular}{ll} 
ARTICLE INFO & ABSTRACT \\
\hline Article History: & The purpose of this study is to determine the opinions of teachers on the application of the Orff- \\
& Schulwerk approach in online lessons. A qualitative descriptive model was employed in the study. \\
Received: 21.01.2020 & The data were obtained through online course observations and interviews carried out with teachers \\
adopting the Orff-Schulwerk approach. The data were analyzed by qualitative content analysis \\
method. It was found that videoconferencing programs in online lessons suppress the sound, and \\
connection and synchronization problems cause many pedagogical disadvantages for Orff- \\
01.09.2021 \\
Schulwerk practices. It was determined that these technological limitations impede group studies in \\
all aspects of music, movement, instrument, and improvisation. Teachers adopting Orff initially \\
followed a reductionist approach by reducing their goals and plans in order to find solutions to these \\
problems. As the process continued, they included additional technologies to online lessons, \\
organized preparation activities before the lessons, and changed the teaching methods and strategies \\
used for the lessons. Furthermore, they created ideas to overcome the limitations of technology and \\
recorded preparation videos. Teachers further stated that the process has advantages such as \\
interacting with the whole world, creating many more and more methodical lesson materials, \\
analyzing with didactic lessons, and developing their own creativity. They stated that technology \\
needs to be developed more in order to carry out Orff-Schulwerk lessons online, and that they would \\
prefer to implement this approach face to face with the conditions at hand for efficiency; however, a \\
time in which they can use the technology more has started.
\end{tabular}

(C) 2021 IOJES. All rights reserved

Keywords:

Music, Music Education, Orff-Schulwerk, Technology, Online Lessons.

\section{Introduction}

Different paradigms have emerged in science, art and education, depending on the developments in other fields. In music education Orff, Kodaly, Gordon, Dalcrose and Suzuki emerged as the pioneers of these new paradigms in the 20th century. Orff-Schulwerk, which is one of these approaches, initiated the transition

${ }^{1}$ Corresponding author's address: Gazi University

Telephone: +905357239183

e-mail: gulsah.sever@gmail.com

DOI: https://doi.org/10.15345/iojes.2021.04.001 
from an environment where virtuosity and higher artistic skills are glorified to an approach that emphasizes the elements of the human beings with movement-music and improvisation. Orff-Schulwerk began as an experimental study to find "a new way of teaching music" that is "artistic rather than purely educational" (Orff, 1978). This approach was critical towards the loss of expression, abilities and creativity innate to humanity under the influence of the European "classical" music tradition (Orff, 1930; Kugler, 2013). In this context, the main purpose of this approach is to reveal the natural expression ability and creativity of the "modern" individuals by returning to state of "primitive" being, that is the soul-mind-body unity (Kugler, 2000). According to (Orff, 1963), elemental music cannot exist by itself; it forms a whole with movement, dance and speech. It is the music produced by the individuals, not as listeners but as participants. Elemental music is close to earth; it is natural, physical, and suitable for everyone to learn and experience. Children reach a deeper understanding of music through creation, improvisation, exploring and experiencing. Adding movement, drama, and visual arts further enriches the learning experience (Lopez- Ibor, 2011). According to Orff, the more basic the foundation of the expression is (basic elements, principles, forms, etc.) and the simpler it is, the stronger its effect (Weinbuch, 2010). Based on these thoughts, Orff shaped his approach with body and body percussion studies, which is the most natural instrument, and instruments such as the wooden xylophone and marimba, which are closest to nature. Orff saw this new concept of musical education as the only way to regain lost skills (Orff, 1930; Kugler, 2000; Jungmair, 2003; Weinbuch, 2010; Kugler, 2013).

\section{Technology in the Orff-Schulwerk Approach}

Until this section, it has been mentioned that the basic philosophy of Orff Schulwerk is to meet the elemental nature of human beings. The crucial part here is that the approach emphasizes on the principles of children's developmental characteristics, language development, and the connection of the instruments and materials used to nature. However, recent studies, especially in early music education, have shown that musical environment and nature of the children have also changed in parallel with social and technological developments, and digital technologies have gained dominance (deVries, 2009; Lamont, 2008; Roulston, 2006; Young, 2009). It is observed that children between the ages of zero to six spend an average of 1 hour and 58 minutes in front of the screen in a typical day (Rideout, Vandewater, \& Wartella, 2003). Many parents today also believe that musical toys and multimedia tools are more efficient at delivering musical experiences to their children than live performances. Parents state that they do not know how to sing (deVries, 2009) and that multimedia materials are prepared and recorded by field experts (Thomas, 2007) and thus are more educational and aesthetically reliable.

This development in digital technologies is also reflected in Orff Schulwerk. According to Yaprak Kotzian (2018) even if the "elemental" idea, which forms the basis of Orff Schulwerk, has the quality of being beyond time, materials of Orff Schulwerk certainly do not have the quality of being beyond time. Nowadays, digitalization and new media have become a natural phenomenon that young generation has met from birth and a natural part of their sociocultural life. These are the current tools that humanity uses to satisfy the innate drive for self-expression and creation and can be described as "new" elemental. Orff teachers should follow and consider all the developments that time has brought and will bring, and adapt them appropriately in elemental musical practice.

In the development of Orff-Schulwerk ever since 1924, it is seen that the materials he produced have changed over time with the technology of the time. It is observed that many devices such as phonograph, gramophone, cassette, CD player are used in Orff studies with the widespread use of recording technologies. (Frazee, 2006) states that the use of these recordings provides access to music from all over the world especially in music listening studies and that the musical understanding of different composers can be experienced in Orff Schulwerk lessons through these recordings. The advantages offered by online digital technologies in recent years and the widespread use of internet at schools and homes and it becoming an integral part of daily 
life have brought a major paradigm shift in learning and education (Teacher Training Agency (TTA) , 1999; Prensky, 2001). In parallel with these developments, materials such as mobile applications, web-based practice assistance programs, videos and slides have started to be used in Orff-Schulwerk practices.

There are studies in the literature that resist and support the use of digital technology. (Goodkin, 2009) states that against the high rate of digitalization in the daily lives of children, technology limitation in Orff lessons will be the antidote of children, and that their learning with a real community contributes to their spiritual development with the union of body-mind-heart. (Koops, 2011) used social networks to communicate with families that support the music education of young children. In this way, he shared knowledge and experience among families. It was found that families gained awareness about their guidance and the development and musical performances of their children. Woody\& Fredericksohn (2000) used Master Tracks Pro and Band-in-a-box programs, Rhode (2018) used DJ sets and MIDI technologies in Orff classes to strengthen accompaniment, create concurrent ostinato parties and work in different musical styles. They stated that these practices reinforce the rhythmic parts played by the students, enrich the ostinato, and the accompaniments made with different musical styles have various contributions in terms of getting to know different world cultures. However, they stated that because Orff is an approach that encourages discovery and diversity, it is very difficult to imagine fully or predominantly technology-supported teaching, and it should be a tool that can be used in Orff-Schulwerk classrooms.

There are also online websites designed for general music education, but with the addition of modules according to the needs of music education approaches. On the MusicPlayOnline platform there are practice suggestions for Orff teachers, sections that allow seeing Orff instruments and playing them by clicking. Murillo (2017) states that these web-based sites, which are in line with international exam standards and provide gradual learning, are used and found beneficial by music teachers. In another study conducted by De Ioris, Moggio \& Giovannella (2012), they developed the TaTi-Conga, a digital toy instrument, which is inspired by model instruments becoming widespread with digital technologies such as Guitar Hero, with enhanced technology that can be used in different active music approaches such as Orff, Kodaly, Dalcrose. TaTi-Conga is a multi-dimensional design that contains rhythmic and melodic sounds, produces the sounds of different Orff instruments when adjusted, allows listening and playing back accompaniment with midi files, and allows learning with repetitions with the help of the virtual teacher. Although it is interesting as a design, its effect on education and learning is not yet known since there are no studies available on its users yet.

For the first time in Orff Schulwerk, Klopper (2010) launched the "Orff-Tswana" Intercultural Music Making Initiative, which includes the music education students of Australian and African universities, using the video conferencing software. They shared the original songs and recordings each other via video conference and Sibelius software. There is no detail in the research about how video conferences took place. It can be thought that this study was used as a communication tool rather than an online lesson design. Based on the studies in the literature, it is seen that the use of digital technologies in Orff-Schulwerk consists of supportive trials aimed at contributing to education as a material.

The global epidemic affecting musical education approaches all over the world has turned digital technologies, which were previously used only as teaching materials, into the basic communication and lesson platform. Orff Schulwerk approach, which has stages such as face-to-face communication, group studies, playing together and improvisation, has encountered the obligation of providing the entire education on a digital platform. Since it is not known how long this obligation will last, it has become important to investigate the experiences of Orff-Schulwerk teachers in order to shed light on further practices. In this context, the aim of the study is to reveal the perspectives of Orff-Schulwerk teachers to determine the methods and strategies that they apply to handle this situation, to learn their opinions on the advantages and disadvantages of online 
lessons. In order to provide a draw framework for this purpose, information about Orff-Schulwerk approach and technology use will be provided.

\section{Method}

\section{Study Design}

This study is a descriptive case study that was created to determine opinions of teachers in the compulsory technology adaptation process of the Orff-Schulwerk approach and to determine the practices in this process with live lesson implementations. Descriptive case studies provide insight into complex issues and describe natural phenomenon within the context of the data that are being questioned (Zainal, 2007). The goal of a qualitative descriptive study is to summarize the experience of the individuals or participants (Lambert, 2012). Guba (1981) suggests the validity of this type of research is increased when different research methods are pitted against each other in order to cross-check data and interpretations. He suggests that different methodologies like 'questionnaires, interviews and documentary analyses' should be used when possible. In this study observation and interview methods were employed to collect research data. There was a total of 36 hours of online live lesson participation for observation. These live lessons include a 20-hour OrffSchulwerk coaching program, 3 online workshops in which 6 different instructors alternately participate, and observation of the international 'Sunday Sharing' days organised by the Finnish Orff Association.

\section{Study Group}

The interviewees were reached with the snowball sampling model. Snowball or chain sampling technique is used when it is difficult to reach the units that make up the population or when information about the population (size and depth of information, etc.) is missing (Patton, 2005). This technique focuses on people and critical situations where rich data can be obtained and reaches the population by following them (Creswell, 2013). A researcher who wants to make a snowball sampling begins by asking the following questions to the people and situations that potentially hold the most knowledge in the population regarding the examined phenomenon: "Who knows the most about this subject? Whom should I start interviewing?" (Flick, 2014). In this way, the researcher tries to get new information by asking people who else they can interview. In this study, people who conduct online lessons and who have higher interaction with other people and institutions were found.

In this context, a person who provides licensed Orff-Schulwerk Teacher Training in Turkey was first contacted and suggestions about who could provide sufficient information were taken. Then, recommendations of each interviewee were sought. Interviews were carried out with 8 teachers in this manner. Detailed information about the working group is given in Table 1.

Table 1. Characteristics of the participants

\begin{tabular}{|c|c|c|c|c|c|}
\hline Code & Gender & Age & Experience Year & Lessons taught & City/Country \\
\hline 01 & $\mathrm{~F}$ & 40 & 16 & Preschool/Orff Teacher Training & Ankara, Turkey \\
\hline $\mathrm{O} 2$ & M & 40 & 15 & Preschool/Orff Teacher Training & Istanbul, Turkey \\
\hline $\mathrm{O} 3$ & M & 30 & 8 & Preschool, Elementary school & Istanbul, Turkey \\
\hline $\mathrm{O} 4$ & M & 30 & 5 & Preschool, Elementary school & Istanbul, Turkey \\
\hline O5 & $\mathrm{F}$ & 40 & 15 & Preschool/Orff Teacher Training & Salzburg, Austria \\
\hline O6 & $\mathrm{F}$ & 38 & 15 & Preschool/ University & Samsun, Turkey \\
\hline O7 & $\mathrm{F}$ & 30 & 10 & Preschool/Orff Teacher Training & Ankara, Turkey \\
\hline O8 & $\mathrm{F}$ & 45 & 13 & $\begin{array}{l}\text { Preschool, University and Orff Teacher } \\
\text { Training }\end{array}$ & Salzburg, Austria \\
\hline
\end{tabular}

All the interviewees are teachers who have graduates from Orff Teacher Training program, have international studies, have done institutional studies to develop the Orff approach at the international level, 
and have Orff teaching experience of 5- 16 years. The identities of the people interviewed in the research were kept confidential upon their requests due to ethical principles and were coded as O1, O2, which means Orff teacher.

\section{Data Collection Tools}

Online lesson observation form and semi-structured interview form were used to collect data in the study. Technology preferences and changes in teaching strategies were recorded on the observation form. There were seven interview questions including the differences in technology use of the Orff approach before and after the isolation process; the effect of the process on the application dimensions of the approach and the advantages and disadvantages of the process. The interview questions were shared with two field experts and one language expert. Necessary changes were made in line with expert opinions. Interviews were conducted online via the Zoom video conferencing program. Further questions were asked according to the course of the interview.

\section{Validity and Reliability}

In qualitative studies, validity-reliability is addressed differently from quantitative studies (Yıldırım \& Şimşek, 2013). Instead of the validity and reliability expressions used in quantitative studies, it would be more correct to mention the expressions such as credibility, accuracy of the results and the competence of the researcher in qualitative studies (Krefting, 1991). Guba and Lincoln (1982) pointed out that validity should be trustworthiness rather than reliability in qualitative studies and categorized the criteria for trustworthiness under four main headings: credibility, reliability, approvability and transferability (Houser, 2015; Merriam, 2013; Whittemore, Chase, \& Mandle, 2001).

Data collection methods were diversified in order to increase the credibility and reliability of this study. Therefore, both interview and observation methods were employed. Interviewees' perceptions of the technology integration process may change. 36 hours of live lesson observation was carried out to determine the extent to which the expressions of the participants that adapted to or resisted against the process and the practices in the lessons coincided. The statements of the interviewees were compared with the live lessons.

\section{Data Analysis}

Qualitative content analysis was used in the analysis of the study data. The data obtained from observations and interviews were deciphered and encoded with MAXQDA 12 qualitative analysis program. First, interviews and observation notes were collected and transcribed. Second, codes were developed. Third, themes and categories were developed based on a literature review. Fourth, the themes, categories, and codes were tabulated and interpreted. The codes and sub-codes were first analyzed by the researcher, then shared with experts, and the analysis was finalized by examining the overlap of the codes and expressions.

\section{Limitations}

This study had two limitations. First, this study is limited to the experience which Orff teachers have built during an average of 9 months of online digital technology. Second, the assessment was based on selfreport and observations.

\section{Findings and Interpretation}

The codes and sub-codes obtained as a result of the qualitative content analysis shown in the table below. 
Table 2. Code System

\begin{tabular}{|c|c|c|}
\hline & Code & Code weight \\
\hline \multirow[t]{8}{*}{1} & Disadvantages & 123 \\
\hline & Technological & 56 \\
\hline & Sound & 24 \\
\hline & Synchronicity & 17 \\
\hline & Screen & 15 \\
\hline & Pedagogical & 67 \\
\hline & Group Studies & 22 \\
\hline & Movement & 9 \\
\hline 2 & Advantages & 36 \\
\hline \multirow[t]{6}{*}{3} & Solutions & 113 \\
\hline & Reduction & 34 \\
\hline & Additional technologies & 29 \\
\hline & Individual- Respective & 19 \\
\hline & Preperations & 13 \\
\hline & Exceeding the limits & 13 \\
\hline
\end{tabular}

Table 2. Code System

\section{Disadvantages}

As a result of the data analysis, the disadvantages encountered by Orff educators are grouped under two main headings: technological and pedagogical.

Technological: Orff Schulwerk lessons are restricted by technological facilities, as all activities during the isolation process have to be held online. It is seen that the disadvantages of the Orff lessons basically stem from this restriction. The answers of the teachers are clustered under three headings as sound, synchronicity and screen limitation.

Sound: The most basic material of musical education is sound. According to the teachers, the most important problem in online classes has been the transmission of sound and voice. Due to the features of online conference programs to suppress loud sounds, frequencies and background noises, the transfer of musical sounds other than the speech was indicated as the major problem. Although there are available program settings to allow the background sounds, the level expected by Orff teachers has not yet been achieved. O3 stated that programs cannot transmit the timbre to the other side, repetitive sounds are turned off by the program, and that the sounds such as whistling, or glockenspiel is muted. In addition, O6 stated that when the internet connection is poor, the voices go across intermittently and occasionally there are fluctuations in rhythm. $\mathrm{O} 2$ mentioned that the lesson passed by trying to fix the problems such as the interruption of the voices, delayed sounds, someone forgetting the microphone off, and there was not enough time left for musical purposes.

O4 criticized sound and connectivity problems in terms of Orff philosophy. "First of all, the sounds are digital, and [students] cannot hear a natural sound. Or for example, let's say students brought an item in the house to play and started hitting the bottle. But it does not matter whether it is a bottle or a drum because a vague sound is transmitted to the other side. Since they cannot distinguish those tunes, cannot hear sounds clearly and cannot listen to each other, we cannot make music at the same time and thus eliminate most of the musical achievements that we expect." Orff teachers tried to improve the sound quality by strengthening the microphone and sound systems, but they stated that they could not individually solve the synchronization problem caused by the delay in the connection. 
Synchronization: The concept of synchronization, which can be defined as performing a piece at the same time in accordance with a tempo is one of the most important essential elements of music and education. By feeling the tempo and rhythm together, playing, singing in choir and orchestral work, all participants are adapted to the same environment at the same time. According to the Orff teachers, it has become impossible to carry out these studies as delays were experienced due to the connection. O8 stated that they made experiments by having all the students to turn on their microphones, opening the voices of everyone in the digital environment created cacophony, so they muted their microphones, and further said that the greatest disadvantage of this for Orff lectures was that the group consisting of 50 participants lost communication with each other.

All the interviewees stated that they could not perform any of the activities involving polyphony such as choir, orchestra, co-improvisation and collective performances due to the synchronization problem. O1 stated that unless this synchronization problem is solved technologically, "I cannot work canon at the same time. We cannot sing two audio tracks. I cannot accompany them while they sing. We cannot bring the small ostinato together at the same time." O6 stated that this situation affected both the studies and the presentations and emphasized that "We cannot present the work that we do together here. We can only take turns. If music, speech, instruments, dance are all involved, we cannot perform it live. We have to be content with just explaining." On the other hand, O5 stated that this problem interrupted making music and dancing together, thus inspiration and creativity.

Screen: One of the technological disadvantages for Orff teachers is being limited by the screen capacity. $\mathrm{O} 3$ and $\mathrm{O} 8$ stated that it was arduous to follow group studies and improvisation because everyone was in different frames and scattered on the Zoom screen. The same is true for the screens of the students. O7 stated that each student uses another device for connection and further added that, "Some devices can prevent other students from being seen on the screen. This is caused due to the settings and the small size of the screen. It is as if the student is not there despite being present. An interaction cannot be fully realized."

$\mathrm{O} 2$, stating that the supervision of the students becomes difficult in the Orff lessons, especially in the dance activities, emphasized that "When we say dance, they leave the screen. In a lesson of my friend, the one of the boys disappeared for a second and came with a cat. The children do not realize that someone is waiting for them on the screen." and pointed out to the importance of parents' support in online lessons. O5 emphasized the difficulty of observing the whole class from the screen. "A teacher in the classroom can easily observe 20-30 students. We can immediately hear what sound is coming from whom, and how we can create a specialized work for that student there. But it is very difficult to do my own job at the same time and to observe what the students are doing one by one and to manage the process on Zoom. Technology does not allow us to hear them all at the same time. It is as if we are teaching to an empty room."

The problem of all participants seeing each other on the screen also affected the improvisation and the inspiration from the others in the Orff approach. O5 explained this situation by stating that "What another friend does while dancing together in Orff inspires the individual. Creative dance proceeds in this way through the process of inspiration. Technology has constrained this inspirational process. Unfortunately, it is not possible to see another friend of mine while walking around the room."

Pedagogical: During the isolation process, Orff lessons were limited with the possibilities of technology, which brought pedagogical disadvantages. According to the statements of the teachers, these disadvantages are clustered under the headings of group studies and movement.

Group studies: Transmission problems occurring in sound and synchronicity have deeply affected the group studies conducted simultaneously. O8 examined this situation in the context of the basics of the Orff approach. According to O8, "Orff is an approach that teaches how to act together. Creating empathy and synergy is the main goal. When it comes to distance education, I cannot do a group study with you. When it is distant, I am only in 
a small square and I cannot feel your breath. I cannot see your reactions. Unfortunately, the situation we are living in is a situation that is totally contrary to our understanding and requires us to think about how to go through this process as educators again."

O1 examined this situation in the context of feedback and interaction. O1 stated that the problem of synchronicity brought about a chain of pedagogical problems with the following expressions: "The group studies is completely shelved because of the synchronization problem. The group gets together, moves, songs are learned, ideas are shared, but it is not possible to make music at the same time. In the choir lesson, the teacher sings everyone's part. The students also sing with the teacher, but the teacher cannot hear them. Did they sing it right? Do their intonations sound correct? Does everyone work the same part? The teacher cannot control them. They have to control themselves."

$\mathrm{O} 3$ and $\mathrm{O} 6$ said that even though there are group rooms in Zoom, these rooms are generally for sharing ideas. O6 states with the following expressions that social learning aspect is reduced: "The important thing in social learning is not only to share ideas, but also to learn by looking at ourselves after observing the flexibility and the movements of the other person while dancing together."

Movement: Orff lessons consist of face-to-face education with the continuous active participation of teachers and students, usually by moving. On the contrary, teachers stated that students sit in front of the screen in online lessons. O5 emphasized with the following expressions that looking at the screen for more than 30 minutes for children up to the age of 11 is very harmful for their brains "Children should be moving. That was the good thing about Orff anyway. It was discovery by moving. It is limiting in every way to conduct it in this manner."

All the teachers stated that the physical conditions of each student are not suitable for movement, they sometimes work in very small spaces and they usually plan movements limited to the upper body in order not to hit the environment. O3 mentioned a short work carried out in the lesson by emphasizing that a small screen also limits the movements. "We tried to make choreography on a rhyme. However, people are always motivated by the upper body. When you do not get up, it makes it difficult to pull the chair and open a space, having problems with seeing and hearing the teacher as you move away from the screen. Therefore, it was limited with hands and the upper body."

Advantages: Although the teachers mentioned the disadvantages of online lessons, they also touched on the positive parts of the process. It was revealed after the content analysis that it has nine different advantages. Teachers stated that the best advantage was to be able to communicate with the whole world. O2, $\mathrm{O} 3$ and $\mathrm{O} 4$ stated that, thanks to the online lessons, they had the opportunity to work with experienced teachers working in Orff institutes such as Finland, America, Brazil and Salzburg, where they would not normally attend due to cost and time. Similarly, O6 and O7 stated that it was very difficult for them to get permission from the institutions when they used to attend to an Orff workshop and that they had to change the whole plan, but now, they could work with world-renowned teachers in the comfort of their own home without problems such as permissions and relocations with online lessons. Furthermore, this process led Orff educators to seek immediate solutions and to work together. According to O4, it has also increased the flow of information and interaction between Orff teachers all over the world.

The isolation process has provided an environment for the teachers around the world to produce creative solutions with a new perspective. O7 explained the creation process with the following expressions: "When we were wondering how to continue the lessons at the beginning, this process led us to creativity. The number of creative instruments increased more than ever. We made instruments from wooden skewers and cork, using materials such as drumsticks, maracas, kitchen tools etc. Whatever is available in the house is involved." 
Another advantage stated by the teachers was that more time was allocated to the analysis and training part of the work. According to O1, "The didactic part of the work was always in the background. In face-to-face training, people mostly want the answer to the question of what and which. Which song was taught? What activity was carried out? But the question of why remains in the background. The parts of how activities differed according to the groups were shallow. Especially for those who strengthen the didactic part of teacher education with online, the practice dimension and return to normal lessons will be much more successful. "It is also stated as an advantage that online courses can be recorded and watched repeatedly. In this way, students have regular materials at their disposal. O1 stated with the following expressions that not only the videos but also all the materials have become organized and accessible from anywhere: "We created an e-learning portal. Everybody uploads their lessons and plans to this portal. Now, our much more detailed files are always available."

Teachers also stated that this process was very relaxing, especially for students who were introverted. Students who suffered from peer bullying and were shy about expressing themselves had the opportunity to experiment freely without experiencing social anxiety with the microphone being turned off during classes. It was observed that the participation of these students in the lessons has increased. The lessons could be taught without interruption due to fewer distractions compared to face-to-face lessons.

Solutions: The second sub-question of the study is to determine which solutions that teachers produce in order to conduct Orff lessons online. After the content analysis, solutions of the teachers were clustered under six headings: reduction, additional technologies, individual-respective studies, preparation and exceeding the limits.

Reduction: The teachers preferred the reduction method primarily in order to continue their Orff lessons online. When observed from a general frame, the class was reduced to screen capacity; movement to upper body exercises; musical instruments to rhythm instruments made at home; experiencing together to making videos and presenting ideas, polyphony to listening; high-level skills such as creativity and improvisation to the level of song learning and imitation. Teachers first preferred to adapt to the environmental conditions. Statements of teachers regarding these limitations are shared in the following.

O7 and O8 stated that "We did exercises to stay within certain movement limits. Just like working on the upper body, arm and finger using the screen." O6 stated that "There was a butterfly dance. We could not dance holding hands on the screen, instead of we danced our fingers with a circular plate."

O3 stated that "The transfer to the instruments occurs with the materials in the house. Non-melodic rhythmic instruments are more appropriate."

O7 stated that "We have to prefer simpler, easier to learn, short songs in song teaching."

As can be understood from the statements, the teachers initially were limited to the screen and planned their lessons with the materials at home. However, as the process continued, they sought different solutions. One of these ways is to use additional technologies to the online environment.

Additional technologies: As the process has continued, Orff teachers have begun to use additional technologies to overcome the limitations of technology. Audio and video recording was used by the teachers specially to solve the problem of polyphony and to enable the students to hear the final version of the piece. Students also created videos with new performances on top of the existing performance to create a polyphony environment, especially in group studies.

O1 stated that even though they did not experience the music in the same environment, they achieved a polyphonic sensation by preparing the improvisation of everyone with video recording and editing programs: "Carl Orff Foundation made a project. They gave a piece of music and asked the participants to complete this piece with their own ostinatos. People shot videos. The teacher cut, edited and put together a composition." However, 
O5 stated that the number of people who can use video recording and editing programs in groups is low, and especially in young groups, recording in rhythm and making it polyphonic by combining this recording is challenging due to the technical infrastructure.

In addition to audio and video recording tools, three teachers stated that they made more use of visual aids such as book pages, scores and pictures representing graphic notation. Only O8 stated that they used digital tools, mobile applications and ready-made loops as an aid to improvisation.

Individual-Respective: As another solution teachers changed their teaching methods and strategies. O8 applied the freezing strategy in movement, improvisation, and singing exercises in online lessons. "One person starts, when he/she is frozen, the other continues. Musically, this can be understood." O6 and O7 wanted their dance moves to be imitated in their workshop, and then they waited for everyone to respectively demonstrate the different movements which they produced. O7 stated that he/she did the rhythm repetitions and reflection studies one by one and respectively. He/she asked the students repeat by playing a rhythm. O3 stated that he/she focused on activities such as questions and answers by first singing short lyrics, rhythms and melodies, and then asking the students to respectively complete. $\mathrm{O} 4$, on the other hand, emphasized that everyone is in a different place in the windows on the screen and sometimes people change places, so the queue is confused and stated that they gave numbers to everyone to solve this problem. According to these numbers, everyone stated that they were doing exercises such as posing, freezing and following others in order.

Preparation: Another solution that teachers found is to do preliminary studies They sent a list before the lesson to collect materials at home. Over time, teachers made their own rhythm instruments with the students. O7 recorded videos explaining how to make an instrument from waste materials such as plastic plates and toilet paper rolls and shared them with the students before the lesson. O2 stated that he/she sent videos to be used for warming up just before the lesson, and that the lesson was more efficient when the students participated by doing these exercises.

Teachers sent videos not only for the material but also to prepare for the topics to be covered in the lesson. The recording of a song and the videos with the lyrics were used by all teachers. O3, O6 and O8 stated that they recorded videos in order to have the students hear the final state of the pieces learned in lessons in parts.

Exceeding the limits: Teachers initially shaped their lessons according to technological limitations. However, as their experience increased, they exceed these limitations. The upper body and fixed practices within the limits of the screen followed a lesson aimed at expanding the space. O1 shared an example: " $A$ colleague of ours gives the children a theme in the live lesson. He/she makes the children prepare materials together with their mothers. This puts children into the atmosphere before the activity starts. He/she says; dig a hole in the middle of the carpet or find something. This keeps the children moving just like in the classroom setting." In this example, the screen stays fixed; the student expands the space by moving away from the screen a little. In another application, $\mathrm{O} 2$ stated that they found solutions such as "moving in the room with the computer in our hands". "For example, we say, let's find something that makes a long noise or a rope. We always stand up to be active. We turn the camera and point our feet. If there is a problem with the position, we fix it." O2 gave an example of how they worked by changing the angle of the camera with these expressions.

$\mathrm{O} 3$ and $\mathrm{O} 4$ enabled the students to leave from and return to the screen as soon as the rhyme was finished with instructions such as "Walk around the house while the rhyme is sung. What did you do in the pandemic? Choose the item you used the most and perform its move. Come walk around the house until the rhyme is over!"

Teachers looked for ways to expand the whole-body movements. O2 stated that "Since our houses are small, we moved the dance lesson to the chair. Yes, this idea was created for online, but we also used stools in regular classes. This way we could also saw each other on the screen." 
In the instrument dimension, while rhythm instruments were practiced mainly with home materials, melodic instruments were tried as well. O7 stated with the following expressions that he/she tried to make melodic experiments with the materials available in the house: "I tried to use glasses. But the glass, amount of water in it and matching the exact notes was important. Even if it does not sound right, at least we tried to catch the fifth interval."

Teachers also experimented with polyphony with sound effects and elongated sounds for synchronization and polyphony. In the workshop organized by $\mathrm{O} 3$ and $\mathrm{O} 4$, each participant imitated different doorbell effects in the doorbell ringing event, and polyphony was achieved by selecting opposing ones (long versus short sound, etc.). $\mathrm{O} 2$ quoted a similar example of working with instruments: "A guitarist and a violinist play at the same time in the practice. The melody and the song are on the guitar, while the violin plays one sound like the sound of the wind. Even a little polyphony is provided."

\section{Conclusion and Recommendations}

In this study, the advantages, and disadvantages of online Orff-Schulwerk lessons and the solutions produced by Orff-Schulwerk teachers were discussed. Orff-Schulwerk lessons are widely given in pre-school institutions. Since both preschool and music education have social and face-to-face aims, teachers working in these fields have been caught unprepared for the distance education process, which has become compulsory with the pandemic. According to Yıldırım (2021), primary and secondary schools continued education with television broadcasts and distance education infrastructures created by the national education ministries during the pandemic. Likewise, higher education institutions have coped with the process by strengthening their existing distance education infrastructures. However, preschool institutions do not have an infrastructure for distance education as required by their programs. According to Rees (2002) music educators have been slow to adopt the internet-based distance education process. The continuation of music education, in practice, in a master-apprentice relationship and in face-to-face environments, and the ossification of this method seems to be an important factor for those who want to take music education and music educators to stay away from distance education (Aksoy, Güçlü, \& Nayir, 2020). This recessive approach, which is expressed in studies such as general music education and vocational instrument education, is seen as an opportunity within the Orff-Schulwerk philosophy. According to Orff-Schulwerk, music is timeless. This is what he means: anything may change. But the roots that date back to the earliest times of our existence and our existence do not change (Yaprak Kotzian, 2018). It was observed that the teachers participating in the study also acted based on this principle and in a short time they organised lesson plans and activities according to the new situation at hand. However, it turned out that existing technology has too many drawbacks to precisely organise an Orff-Schulwerk lesson. Especially the problems in the transmission of sound, and the problem of connection and synchronization that prevents making music together at the same time caused pedagogical difficulties. Therefore, polyphony and group studies, which are indispensable for Orff-Schulwerk approach, could not be carried out.

According to Digolo, Andang'o, \& Katuli, (2011) the problems to be overcome in distance music education are 1) Lack of distance music education pedagogy, 2) Lack of competence in using technology, 3) Lack of software for music and instrument education, and 4) Low internet quality and connection speed. Yildirım (2021) also states that the most common problem that preschool teachers encounter in the distance education process is internet connection. As a result, he stated that not all students can be accessed, and it becomes difficult to reach pedagogical goals. In the same study, teachers offered suggestions such as strengthening the internet infrastructure, informing parents about the process, requesting parents to send video recordings of activities at home, preparing television programs by the Ministry of National Education, and providing in-service training to teachers. These recommendations point to problems that can be solved by stakeholders other than teachers. Orff-Schulwerk teachers, on the other hand, sought the solution within 
themselves because they worked in a much more specific field. Orff-Schulwerk teachers, as a solution, firstly reduced their goals with a reductionist approach. The class was reduced to screen capacity; movement to upper body exercises; musical instruments to rhythm instruments made at home; experiencing together to making videos and presenting ideas, polyphony to listening; high-level skills such as creativity and improvisation to the level of song learning and imitation. Thus, the teacher assumed a one-sided information transmitter role, and the students worked individually in their own homes under the instructions of the teacher. Student-to-teacher feedback was only available through solo parts carried out in turns or video assignments. Furthermore, the interaction of students with each other decreased significantly. It was observed that learning and activities became more individual. However, what is meant by individuality here is far from an education organized according to the learning facilities and differences of each individual, as in today's constructivist learning approaches. Instead, it refers to a lesson environment that is free from the interaction and feedback that each student tries to get by watching the teacher. Therefore, it can be said that the responsibility of learning lies more on the students. As this process continued, teachers created solutions to overcome the limitations of technology by using additional technologies such as audio and video recordings, giving instructions to students to prepare before the lesson and changing their teaching strategies.

This process also had advantages. According to Dodds, Perraton, \& Young (1972), distance education has grown due to three perceived main advantages. The first of these is its economic advantage: in distance education, school buildings are not required and far more students can be trained than the school building can accommodate. Its second main advantage is its flexibility: people who work in a job can participate in educational activities in their own free time and at home without having to leave their jobs. The third advantage is that it has the capacity to educate a very large group of people (from nomads to inmates). Kılınç, Yazıc1, Günsoy, \& Günsoy (2020) states that distance education can have important functions in terms of decreasing the costs, providing education to the masses, increasing the income and welfare level especially in populated countries. Khan\& Williams (2006) argue that distance learning platforms are powerful tools to reduce poverty and increase the social welfare of low-income people, the disabled, long-term patients, minorities and similar disadvantaged groups. In this study As the distances lost their importance, the interaction of Orff-Schulwerk teachers from all over the world came together to produce solutions and to hold share days. It was opportunity to participate in workshops, which are difficult in terms of time, distance, and costs in face-to-face education, with the comfort of the home and low costs.

As another advantages creativity of the teachers developed in this process, they made different instruments from various materials, and devised different teaching strategies and new methods. The teachers recorded more of their work and made them available 7/24, ensured the formation of regular lesson materials. Especially in teacher training, it was stated that a deeper insight was gained about why and how practices were carried out by didactic analysis of the previously applied lessons. This result is determined for a qualified distance education environment; $24 / 7$ access to course materials, flexibility, video, audio, graphics, diversity, high interaction and collaboration opportunities are in line with research in the literature (Meyer, Rose, \& Gordon, 2014; Harasim, 2017; Henderson, Selwyn, \& Aston, 2017; O'Callaghan, Neumann, Jones, \& Creed, 2017).

Become better on the online platform, new technologies that can solve synchronization and audio transmission problems must be developed. Therefore, it is important to share the results of this study with people working in the field of internet and software. Teachers should have easy access to products such as microphones and mixers that can improve the online lesson experience. This access should be provided with institutional support since the technological knowledge and financial situation of each teacher will vary. The sharing days regarding the solution of the problems that occurred in our country and Orff-Schulwerk 
institutes and associations in different parts of the world and the development of new lesson methods should be followed, and these should be reported and shared with all colleagues.

This study is limited to the experience which Orff-Schulwerk teachers have built during an average of 9 months of online digital technology. It was observed that teachers spent the first three months with technological decisions such as understanding technological limitations, transmitting better audio and deciding on video conference programs, and the next three months acknowledging the limitations of technology and making lesson plans accordingly. In the last three months, it was observed that ideas started to be generated rapidly in order to overcome these limitations. Therefore, it is recommended that the study is reconstructed and updated as experience increases. 


\section{REFERENCES}

Aksoy, Y., Güçlü, O., \& Nayir, A. E. (2020). Özel müzik kurslarının pandemi sürecindeki uzaktan eğitim durumları. Milli Ĕ̆itim Dergisi, 49(1), 947-967. doi:10.37669/milliegitim.827709

Creswell, J. W. (2013). Research Design: Qualitative, Quantitative, And Mixed Methods Approaches. . New York: Sage.

De Ioris, L., Moggio, F., \& Giovannella, C. (2012). Beyond the "Orff Schulwerk": Toward a new approach to the technology enhanced musical education. IEEE 12th International Conference on Advanced Learning Technologies. doi:https://doi.ieeecomputersocie

deVries, P. (2009). Music at home with the under fives: What is happening? Early Child Development and Care, 179(4), 395-405.

Digolo, B. A., Andang'o, E. A., \& Katuli, J. (2011). E-Learning as a strategy for enhancing access to musiceducation. International Journal of Business and Social Science, 2(11), 135-139.

Dodds, T., Perraton, H., \& Young, M. (1972). One year's work: The International Extension College 1971-1971. International Extension College.

Flick, U. (2014). An Introduction to Qualitative Research. New York: Sage.

Frazee, J. (2006). Orff Schulwerk today: Nurturing musical expression and understanding. New York: NY: Schott Music.

Goodkin, D. (2009). Pause and consider: Electronic technology and Orff Schulwerk. Orff Echo, 42(1), 20-23.

Guba, E. (1981). Critique for assessing the trustworthiness of natural inquires. ERIC/ECTJAnnual Review Paper," 29(2), 75-91.

Guba, E. G., \& Lincoln, Y. S. (1982). Epistemological and methodological bases of naturalistic inquiry. Educational Communication and Technology Journal, 30(4), 233-252.

Harasim, L. (2017). Learning theory and online technologies. . Taylor \& Francis.

Henderson, M., Selwyn, N., \& Aston, R. (2017). What works and why? Student perceptions of "useful" digital technology in university teaching and learning. Studies in Higher Education, 42(8), 1567-1579.

Houser, J. (2015). Nursing research: reading, using, and creating evidence. (3 b.). Burlington: Jones ve Bartlett Learning.

Jungmair, U. (2003). Das Elementare. Zur Musik-und Bewegungserziehung im Sinne Carl Orffs. Mainz. : Schott, .

Khan, H., \& Williams, J. B. (2006). Poverty alleviation through access to education: Can e-learning deliver? C. A. Tisdell (Dü.) içinde, Poverty, poverty alleviation, and social disadvantage: analysis, case studies and policies. . Serials Publications.

Kılınç, B. K., Yazıcı, B., Günsoy, B., \& Günsoy, G. (2020). Perceptions and opinions of graduates about theeffects of open and distance learning in Turkey. Turkish Online Journal of Distance Education, 21(1), 121-132. doi:https://doi.org/10.17718/tojde.690369

Klopper, C. (2010). Intercultural musicianship: a collective and participatory form of music exchange across the globe. Australian Journal of Music Education., 48-57. http://files.eric.ed.gov/fulltext/EJ912415.pdf adresinden alındı 
Koops, L. H. (2011). Music play zone: An online social network site connecting parents and teacher in an Early Childhood Music Class in Learning from Young Children. C. C. Suzanne L. Burton (Dü.) içinde, Learning from Young Children: Research in Early Childhood Music.

Krefting, L. (1991). Rigor in qualitative research: the assessment of trustworthiness. The American Journal of Occupational Therapy, 45(3), 214-222.

Kugler, M. (2000). Die Methode Jacques- Dalcrose und das Orff-Schulwerk Elementare Musikübung: Bewegungsorientierte Konzeptionen der Musikpadagogogik. Frankfurt am Main: Peter Lang.

Kugler, M. (2013). School and Teaching . M. Kugler (Dü.) içinde, In Elemental Dance - Elemental Music: The Munich Günther School 1924-1944 (M. Murray, Çev., s. 213-241). New York: Schott Music Corporation.

Lambert, V. a. (2012). Editorial: qualitative descriptive research: an acceptabledesign". Pacific Rim International Journal of Nursing Research, 16, 255-256.

Lamont, A. (2008). Young children's musical worlds: Musical engagement in 3-5-year-olds. , 6, . Journal of Early Childhood Research(6), 247-261. doi:https://doi.org/10.1177/1476718X08094449

Lopez- Ibor, S. (2011). Blue is the sea: Teaching the whole child throuhg music- music, dance and visual arts. The pentatonic press integrated learning series.

Merriam, S. B. (2013). Nitel araştırma desen ve uygulama için bir rehber. (S. Turan, Çev.) Ankara: Nobel Yayıncılık.

Meyer, A., Rose, D., \& Gordon, D. (2014). Universal design for learning: Theory and practice. CAST.

Murillo, R. E. (2017). The 21st century elementary music classroom and the digital music curriculum: A synergism of Technology and traditional pedagogy. Texas Music Education Research., 14-27. https://files.eric.ed.gov/fulltext/EJ1183312.pdf adresinden alınd1

O'Callaghan, F. V., Neumann, D. L., Jones, L., \& Creed, P. (2017). The use of lecture recordings in higher education: A review of institutional, student, and lecturer issues. Education and Information Technologies, 22(1), 399-415. doi:https://doi.org/10.1007/s10639-015-9451-z

Orff, C. (1930). Movement and music education as a Unity. M. Kugler (Dü.) içinde, Elemental Dance - Elemental Music: The Munich Günther School 1924-1944 (M. Murray, Çev., s. 146-148). New York: Schott Music Corporation.

Orff, C. (1963). Orff Schulwerk: Past and future . Opening speech of the Orff Institute at October 25 Trans. Margaret Murray. Salzburg.

Orff, C. (1978). The Schulwerk. New York: Schott Music Corp. .

Patton, M. Q. (2005). Qualitative Research. New York: John Wiley \& Sons, Ltd.

Prensky, M. (2001). Digital natives, digital immigrants. On the Horizon, 9(5). http://www.nnstoy.org/download/technology/Digital+Natives+-+Digital+Immigrants.pdf adresinden alınd 1

Rees, F. J. (2002). Distance Learning And Collaboration in Music Education,. R. C. Richardson (Dü.) içinde, The New Handbook Of Research In Music Education, (s. 257). New York: Oxford University Press.

Rhode, D. (2018). Techno- Schulwerk: Electronic inspiration for elemental music making. Orff Echo, 50(3), 5459. https://aosa.org/wp-content/uploads/2018/02/The-Orff-Echo-Spring-2018.pdf adresinden alınd1

Rideout, W. C., Vandewater, E. A., \& Wartella, E. A. (2003). Zero to Six: Electronic Media in the Lives of Infants. Henry J. Kaiser Family Foundation. Menlo Park, CA.: Henry J. Kaiser Family Foundation. https://files.eric.ed.gov/fulltext/ED482302.pdf adresinden alındı 
Roulston, K. (2006). Qualitative investigation of young children's music preferences. . International Journal of Education and the Arts, 7(9). http://www.ijea.org/v7n9/ adresinden alınd1

Teacher Training Agency (TTA) . (1999). Using Information and Communications Technology to meet teaching objectives in secondary music. London: TTA.

Thomas, S. G. (2007). Buy baby buy: How consumer culture manipulates parents and harms young minds. . NewYork, : Houghton Mifflin.

Weinbuch, I. (2010). Das musikalische Denken und Schaffen Carl Orffs. Ethnologische und interkulturelle Perspektiven, . Mainz. : Schott.

Whittemore, R., Chase, S. K., \& Mandle, C. L. (2001). Validity in qualitative research. Qualitative Health Research, 11(4), 522-537.

Woody, R. H., \& Frederickson, J. M. (2000). A partnership project: Integrating computer technology and OrffSchulwerk.

General

Music

Today(Winter).

https://search.proquest.com/openview/e300c05ba352004779635f13e625624c/1?cbl=45392\&pqorigsite $=$ gscholar adresinden alınd 1

Yaprak Kotzian, E. (2018). Orff-Schulwerk: Elementer Müzik ve Hareket Pedagojisinin Temelleri. İstanbul: Pan Yayınları.

Yıldırım, A., \& Şimşek, H. (2013). Sosyal bilimlerde nitel araştırma yöntemleri (9 b.). Ankara:: SeçkinYayıncılık.

Yıldırım, B. (2021). Preschool Education in Turkey During the Covid-19 Pandemic: A Phenomenological Study. Early Childhood Education Journal. doi:https://doi.org/10.1007/s10643-021-01153-w

Yıldırım, B. (2021). Preschool Education in Turkey During the Covid-19 Pandemic: A Phenomenological Study. Early Childhood Education Journal. doi:https://doi.org/10.1007/s10643-021-01153-w

Young, S. 1. (2009). Towards constructions of musical childhoods: Diversity and digital technologies. Early Child Development and Care,(179), 695-705. doi:https://doi.org.10.1080/03004430902944908

Zainal, Z. (2007). Case study as a research method. Jurnal Kemausiaan, 9, 1-6. http://psyking.net/htmlobj3837/case_study_as_a_research_method.pdf adresinden alındı 